\title{
PELAKSANAAN HAK-HAK PEKERJA HARIAN LEPAS PADA HOTEL BINTANG BALI RESORT
}

\author{
Oleh: \\ I Made Dwi Anugrah Putra** \\ I Made Udiana*** \\ I Made Dedy Priyanto**** \\ Bagian Hukum Bisnis Fakultas Hukum Universitas Udayana
}

\begin{abstract}
ABSTRAK
Beberapa kasus yang terdapat pada hotel di daerah Kabupaten Badung adalah masih terdapat beberapa pekerja harian lepas yang telah bekerja selama enam tahun namun belum mendapatkan pengangkatan menjadi pekerja tetap. Salah satu hotel di daerah Kabupaten Badung yang memperkerjakan pekerja harian lepas selama enam tahun bekerja yaitu Hotel Bintang Bali Resort. Hal tersebut sebenarnya bertentangan dengan Undang-Undang Nomor 13 Tahun 2003 Tentang Ketenagakerjaan dan Keputusan Menteri Tenaga Kerja dan Transmigrasi Nomor 100 Tahun 2004 tentang Pelaksanaan Perjanjian Kerja Waktu Tertentu.

Dalam penelitian ini permasalahan yang diangkat adalah bagaimana pelaksanaan hak-hak pekerja harian lepas pada Hotel Bintang Bali Resort serta apakah hambatan dalam pelaksanaan pemberian hak-hak pekerja harian lepas pada Hotel Bintang Bali Resort. Penelitian ini menggunakan penelitian hukum empiris.

Berdasarkan hasil penelitian bahwa pelaksanaan hak-hak pekerja/buruh dengan sistem harian lepas termasuk kedalam sistem perjanjian kerja waktu tertentu (PKWT) pada Hotel Bintang Bali Resort belum berjalan sesuai aturan yang berlaku, karena masih adanya pelanggaran dalam pelaksanaanya, yaitu di bidang hak cuti yang dibayarkan, serta hak untuk menjadi pekerja tetap.

Hambatan yang dihadapi dalam terlaksananya pemberian hak-

*Jurnal dibuat berdasarkan ringkasan skripsi.

${ }^{* *}$ Penulis Pertama dalam penulisan ini ditulis oleh I Made Dwi Anugrah Putra adalah Mahasiswa Fakultas Hukum Universitas Udayana.

${ }^{* * *}$ Penulis Kedua dalam penulisan ini ditulis oleh I Made Udiana adalah Dosen Fakultas Hukum Universitas Udayana.

${ }^{* * * *}$ Penulis Ketiga dalam penulisan ini ditulis oleh I Made Dedy Priyanto adalah Dosen Fakultas Hukum Universitas Udayana.
\end{abstract}


hak pekerja harian lepas pada Hotel Bintang Bali Resort adalah aturan perusahaan mengenai jumlah karyawan tetap sehingga pekerja harian lepas tidak dapat langsung diangkat menjadi pekerja tetap setelah bekerja lebih dari tiga tahun. Faktor kesadaran hukum yang belum memahami peraturan dari pihak Hotel Bintang Bali Resort mengenai hubungan kerja perjanjian kerja waktu tertentu, dan hak cuti yang dibayarkan.

\title{
Kata Kunci : pelaksanaan hak, pekerja, harian lepas
}

\begin{abstract}
Some of the cases found in hotel in the Badung Regency area are that there are still some casual daily worker who have worked for six years but have not yet been appointed to be permanent worker. One of the hotel in the Badung Regency area that employs daily worker for six years working is Bintang Bali Resort Hotel. This is actually contrary to Law Number 13 of 2003 concerning Manpower and Decree of the Minister of Manpower and Transmigration Number 100 of 2004 concerning Implementation of Certain Time Work Agreements.

This research focus on the implementation of the rights of daily worker at the Bintang Bali Resort Hotel and what are the obstaceles in the implementation of the rights of casual daily worker at the Bintang Bali Resort Hotel. This research use empirical legal research.

Based on the results of the research that implementation of the rights of workers/laborers with a daily worker system in this case included in the system of a certain time agreement (PKWT) at Bintang Bali Resort Hotel has not yet proceeded according to the applicable rules, because there are still violations in the implementation, namely in the field of paid leave rights and the right to become permanent worker.

The obstacles faced in implementing the rights of daily worker at Bintang Bali Resort Hotel are company rules regarding the number of permanent employees so that casual daily worker cannot be immediately appointed as permanent workers after working for more than three years. Legal awareness factor that does not yet understand the rules of the Bintang Bali Resort Hotel regarding the employment relationship of a certain time work agreement, and paid leave rights.
\end{abstract}

\section{Keywords: implementation of rights, workers, daily worker}




\section{PENDAHULUAN}

\subsection{Latar Belakang}

Perjanjian kerja harian lepas kerap digunakan pelaku bisnis ${ }^{1}$ terutama industri perhotelan karena memiliki tingkat efisiensi anggaran yang baik bagi pihak manajemen. Sebagai contoh pihak manajemen suatu hotel akan memiliki acara yang diselenggarakan di hotel tersebut dengan skala besar, yang dimana memerlukan tambahan tenaga kerja bersifat sementara saja. Momentum tersebut yang akan membuat pihak manajemen hotel mencari tenaga kerja harian lepas untuk mengisi kekurangan tenaga tersebut.

Realitas dilapangan masih banyak pekerja/buruh harian lepas bekerja selama 30 hari dalam waktu tiga bulan berturut-turut. Peraturan Ketenagakerjaan tidak mengatur tentang pekerja/buruh harian lepas kontrak tahunan. Maka, beberapa hotel pun memanipulasi aturan ini. Banyak pekerja/buruh harian lepas tidak mengetahui bahwa secara hukum, jika mereka lebih dari 20 hari selama tiga bulan berturut-turut ataupun lebih, maka secara otomatis, status mereka sudah menjadi pegawai tetap. ${ }^{2}$ Akibatnya, tidak adanya jaminan bahwa pekerja/buruh harian lepas pasti akan diangkat sebagai pekerja tetap.

Permasalahan yang terjadi pada industri perhotelan tersebut menyebabkan para pekerja/buruh dengan perjanjian kerja harian lepas kurang memiliki perlindungan hukum terutama perihal perlindungan hukum terhadap upah yang diberikan. Pada tahun 2017, biaya upah rata-rata dari pekerja dengan kontrak kerja harian

1 Made Udiana, 2011, Rekonstruksi Pengaturan Penyelesaian Sengketa Penanaman Modal Asing, Udayana University Press, Denpasar, h. 12

2 Eko Wahyudi, Wiwin Yulianingisih, dan Moh. Firdaus Sholihin, 2016, Hukum Ketenagakerjaan, Sinar Grafika, Jakarta, h. 16 
lepas adalah sebesar Rp 75.000 per hari selama bekerja 8 jam. Berdasarkan penelitian yang dilakukan oleh Winata pada tahun 2015, dinyatakan bahwa pada beberapa hotel di Bali seperti contoh pada Four Season Hotel Sayan Ubud dapat dilihat bahwa penerapan standar upah pekerja/buruh harian lepas dibawah rata-rata. Hal tersebut dikarenakan terdapat beberapa pekerja/buruh harian lepas yang telah bekerja selama 2 tahun sejak tahun 2014 dan menggunakan standar gaji yang masih sama dengan tahun 2014 tersebut.

Perekrutan pekerja/buruh harian lepas tersebut dilakukan atas kesepakatan pihak manajemen dengan pekerja itu sendiri. Perekutan pekerja/buruh harian lepas mengingat jumlah karyawan tetap yang dimiliki pada hotel sudah sangat banyak. Hotel Bintang Bali Resort memiliki beberapa peraturan yang melindungi hak-hak para pekerja/buruh harian lepas seperti gaji sesuai Upah Minimum Provinsi Bali (UMP) dan Upah Minimum Kabupaten/Kota (UMK), tunjangan makan dan tunjangan transportasi.

Beberapa kasus yang terdapat pada hotel di daerah Kabupaten Badung adalah masih terdapat beberapa pekerja/buruh harian lepas yang telah bekerja selama enam tahun namun belum mendapatkan pengangkatan menjadi karyawan tetap. Salah satu hotel di daerah Kabupaten Badung yang memperkerjakan pekerja/buruh harian lepas selama 6 tahun bekerja yaitu Hotel Bintang Bali Resort. Berdasarkan wawancara dengan Bapak Muhadir sebagai Human Resource Manager (HRM) Hotel Bintang Bali Resort, mengatakan bahwa Hotel Bintang Bali Resort merupakan salah satu hotel berbintang lima di Kuta memiliki total pegawai sebanyak 250 orang, 
diantaranya 200 orang tersebut merupakan pekerja tetap dan 50 orang pekerja harian lepas. (wawancara tanggal 19 September 2018)

Beberapa dari pekerja/buruh harian lepas di Bintang Bali Resort telah bekerja selama 6 tahun tanpa pengangkatan menjadi pegawai tetap. Pembaharuan kontrak kerja pada pekerja/buruh harian lepas dilakukan lebih dari 3 tahun, dan tahun-tahun berikutnya tetap sebagai pekerja/buruh harian lepas dan tidak terdapat pengangkatan sebagai pekerja tetap. Hal itu sebenarnya bertentangan dengan Undang-Undang Nomor 13 Tahun 2003 Tentang Ketenagakerjaan dan Keputusan Menteri Tenaga Kerja dan Transmigrasi Nomor 100 Tahun 2004 tentang Pelaksanaan Perjanjian Kerja Waktu Tertentu.

Penelitian ini dibatasi pada ruang lingkup pekerja/buruh harian lepas yang terikat dalam perjanjian kerja waktu tertentu $(\text { PKWT })^{3}$ pada Hotel Bintang Bali Resort yang merupakan sebuah Hotel berbintang lima yang berada di daerah Kuta, tepatnya berada di Jalan Kartika Plaza, Kuta, Kabupaten Badung, Provinsi Bali. Pada penelitian ini difokuskan pada lingkup hak-hak pekerja/buruh harian lepas seperti hak atas upah layak, perlindungan waktu kerja, hak atas keselamatan dan kesehatan kerja, dan hak atas kesejahteraan dan jaminan sosial. ${ }^{4}$

3 Cristoforus Valentino Alexander Putra, 2017, "Urgensi Klausula Definisi Dalam Perjanjian Kerja”, Kertha Patrika, vol. 39, no. 1, April 2017, h. 70, https://ojs.unud.ac.id/index.php/kerthapatrika/article/dwonload/32709-94963923-1-10-20170803.pdf. Diakses tanggal 23 Januari 2019 pukul 11.00 WITA.

4 I Wayan Agus Vijayantera, 2016, "Pengaturan Tunjangan Hari Raya Keagamaan Sebagai Hak Pekerja Setelah Diterbitkan Peraturan Menteri Tenaga Kerja Nomor 6 Tahun 2016", Kertha Patrika, vol. 38, no. 1, Januari-April 2016, h. 44, https://ojs.unud.ac.id/index.php/kerthapatrika/article/downloads/30091-158616-1-10 20170420.pdf. Diaskses tanggal 23 Januari 2019 pukul 11.00. 
Jadi berdasarkan atas latar belakang masalah diatas, penelitian ini akan membahas mengenai:

\section{"Pelaksanaan Hak-Hak Pekerja Harian Lepas Pada Hotel Bintang Bali Resort"}

\subsection{Rumusan Masalah}

Berdasarkan latar belakang di atas, adapun permasalahan yang dapat peneliti rumuskan adalah

1. Bagaimanakah pelaksanaan hak-hak pekerja/buruh harian lepas pada Hotel Bintang Bali Resort?

2. Apakah hambatan dalam pelaksanaan hak-hak pekerja/buruh harian lepas pada Hotel Bintang Bali Resort?

\subsection{Tujuan Penelitian}

Tujuan dari penelitian penelitian ini adalah untuk memahami pelaksanaan hak-hak pekerja/buruh harian lepas pada Hotel Bintang Bali Resort dan untuk memahami hambatan dalam pelaksanaan pemberian hak-hak pekerja/buruh harian lepas pada Hotel Bintang Bali Resort.

\section{ISI MAKALAH}

\subsection{Metode Penelitian}

Penulisan skripsi ini menggunakan jenis penelitian hukum empiris. Penelitian hukum empiris merupakan penelitian ilmiah yang menjelaskan fenomena hukum tentang terjadinya kesenjangan antara norma dengan perilaku masyarakat (kesenjangan antara das 
sollen dan das sein atau antara yang seharusnya dengan senyatanya di lapangan). ${ }^{5}$

\subsection{HASIL DAN PEMBAHASAN}

\subsubsection{Hak-Hak Pekerja Harian Lepas Pada Hotel Bintang Bali Resort.}

Berdasarkan keterangan wawancara dilakukan kepada Ibu Wati selaku pekerja harian lepas pada bagian Cook Helper di Hotel Bintang Bali Resort adalah sebagai berikut:

Perlindungan ekonomis atau upah yang diberikan oleh pihak hotel terhadap pekerja/buruh harian lepas seperti saya memang sudah sesuai dengan Upah Minimum Kabupaten sesuai letak Hotel yang berada di kabupaten Badung tahun 2018 sebesar Rp. 2.499.580, sedangkan upah bersih yang diterima Ibu Wati adalah sebesar Rp. 3.172.000, setiap bulan penuh selama 26 hari kerja. Kemudian waktu kerja Ibu Wati bekerja selama 8 jam per hari, dengan jam kerja mulai pukul 08.00 WITA-16.00 WITA, dengan waktu istirahat selama 1 jam. Pekerja/buruh harian lepas juga mendapatkan tunjangan uang makan sebesar 15.000 perharinya dan tunjangan transportasi sebesar 10.000 perharinya. Perlindungan sosial yang di dapat yaitu Ibu Wati juga di daftarkan dalam program BPJS, baik BPJS Kesehatan dan BPJS Ketenagakerjaan. Dan Perlindungan teknis yang diberikan pihak hotel yaitu mengadakan pelatihan untuk menanggulangi terjadinya bencana alam seperti tsunami karena lokasi Hotel Bintang Bali Resort berdekatan dengan pantai kuta, selain itu juga pekerja/buruh diberikan waktu

5 Fakultas Hukum Universitas Udayana, 2013, Pedoman Pendidikan Fakultas Hukum Universitas Udayana, Denpasar, h. 77 
penyesuaian lingkungan kerja dengan alat-alat yang dipergunakan di hotel yang belum terbisa digunakan.

Keluhan selama bekerja di Hotel Bintang Bali Resort adalah dimana Ibu Wati tidak diangkat menjadi pekerja tetap (PKWTT) di hotel tersebut. Alasan dari pihak manajemen menyatakan bahwa kuota untuk pegawai tetap dalam struktur kepegawaian masih penuh. Hal tersebut menyebabkan tidak terdapat pengangkatan kepada Ibu Wati selama jumlah pegawai tetap telah memenuhi kuota. Sejauh ini Bintang Bali Resort memiliki total 250 pegawai, dimana terdapat 200 pegawai tetap dan 50 pekerja harian lepas. Jika terdapat pegawai tetap yang pensiun, baru pembukaan kesempatan bagi pegawai harian lepas untuk berebut menjadi pegawai tetap (PKWTT). Perbedaan kompensasi finansial yang diberikan kepada pegawai tetap dan pegawai harian lepas cukup berbeda. Sebagai contoh pegawai harian lepas hanya mendapatkan gaji pokok, tunjangan makan dan transportasi, sedangkan pegawai tetap mendapatkan gaji pokok, bonus, service charge, THR dan tunjangantunjangan lainya. Alasan saya untuk tetap bekerja disini adalah karena lokasi hotel yang sangat dekat dengan rumah. Selain itu kendala usia bagi ibu Wati membuat beliau merasa tidak percaya diri untuk mencari pekerjaan baru di hotel lain. Pendapatan pekerja harian lepas di Bintang Bali Resort adalah sebesar Rp. 97.000 per hari, dimana satu bulan penuh dapat bekerja. (wawancara pada tanggal 19 September 2018).

Berkaitan dengan perlindungan tenaga kerja berdasarkan teori Imam Soepomo yang diterapkan di Hotel Bintang Bali Resort yaitu: 
1. Perlindungan Ekonomis dengan memberikan pekerja/buruh harian lepas sesuai dengan Upah Minimum Kabupaten Badung.

2. Perlindungan Sosial dengan mendaftarkan seluruh pekerja/buruh tetap maupun pekerja/buruh kontrak dalam program BPJS, baik BPJS Kesehatan dan BPJS Ketenagakerjaan.

3. Perlindungan Teknis dengan memberikan pelatihan kerja untuk mampu menyesuaikan lingkungan kerja dan pelatihan menanggulangi terjadinya bencana alam. ${ }^{6}$

Perlindungan terhadap tenaga kerja dimaksudkan untuk menjamin hak-hak pekerja/buruh dan menjamin kesamaan kesempatan serta perlakuan tanpa diskriminasi atas dasar apa pun untuk mewujudkan kesejahteraan buruh dan keluarganya dengan tetap memperhatikan perkembangan kemajuan dunia usaha. ${ }^{7}$

Selanjutnya berdasarkan wawancara dengan Ibu Lina sebagai pekerja harian lepas pada bagian housekeeping pada Hotel Bintang Bali Resort menyatakan bahwa:

Pekerja harian lepas harus tetap bekerja penuh selama 26 hari kerja. Cuti memang diberikan kepada pekerja harian lepas yang telah bekerja minimal satu tahun sebanyak 12 hari kerja. Namun atas dasar sistem perjanjian kerja bersifat harian lepas, cuti tersebut tidak termasuk cuti berbayar yang artinya gaji dari pekerja harian lepas akan tetap dibayarkan sesuai dengan hari kerja yang terlaksana. Maka dari itu cuti tersebut dikeluhkan oleh para pekerja harian lepas seperti saya dimana saya sangat susah untuk mendapatkan hak cuti karena

${ }^{6}$ Eko Wahyudi, Wiwin Yulianingisih, dan Moh. Firdaus Sholihin, op.cit., h. 33

7 Made Udiana, 2015, Kedudukan Dan Kewenangan Pengadilan Hubungan Industrial, Udayana University Press, Denpasar, h. 4 
pemotongan gaji tersebut. (wawancara pada tanggal 19 September 2018).

Berdasarkan hal tersebut seharusnya pihak Hotel Bintang Bali Resort harus memberikan cuti berbayar kepada para pekerja/buruh harian lepasnya. Karena jika pekerja/buruh harian lepas tetap dipotong upahnya selama mengambil hak cuti sebanyak 12 hari selama setahun, maka pihak hotel telah melanggar Undang-Undang Ketenagakerjaan sebagaimana yang disebutkan dalam Pasal 93 ayat (2) huruf g bahwa pengusaha/pemberi kerja wajib membayar upah apabila pekerja/buruh melaksanakan hak istrirahat. ${ }^{8}$

Berdasarkan hal tersebut dapat dilihat bahwa pelaksanaan perlindungan hak-hak pekerja/buruh harian lepas tidak terlaksana sesuai peraturan ketenagakerjaan yang berlaku. Hal tersebut kontradiktif dengan hasil wawancara dengan Pak Muhadir sebagai Human Resource Manager di Hotel Bintang Bali Resort. Seharusnya pihak manajemen hotel memberikan semua hak-hak yang telah diatur dan dilindungi oleh peraturan perundang-undangan ketenagakerjaan kepada setiap pekerja/buruh termasuk pekerja/buruh harian lepas.

Berdasarkan Undang-Undang Nomor 13 tahun 2003 tentang ketenagakerjaan, perusahaan yang mempekerjakan lebih dari 10 tenaga kerja atau membayar upah paling sedikit Rp 1.000.000/bulan wajib mengikut sertakan karyawannya dalam program Jamsostek. Mengenai hak jaminan sosial tenaga kerja dan keselamatan kerja, bapak Muhadir selaku Human Resources Manager menjelaskan bahwa:

8 Abdul Khakim, 2009, Dasar-Dasar Hukum Ketenagakerjaan Indonesia, PT. Citra Aditya Bakti, Bandung, h. 323 
Untuk jaminan sosial seperti BPJS semua karyawan sudah tercover. Baik karyawan sekeleas General Manager hingga harian lepas. Namun hanya dibedakan dari kelas BPJS tersebut. Untuk pekerja harian lepas mendapatkan kelas II sedangkan kelas supervisor keatas mendapatkan kelas I. Biaya BPJS ditanggung oleh perusahaan sebesar 40\%, sedangkan sisanya dibayarkan oleh pekerja tersebut. Perihal keselamatan kerja, pihak Hotel Bintang Bali Resort mengadakan pelatihan untuk menanggulangi terjadinya bencana alam seperti tsunami karena lokasi Hotel Bintang Bali Resort berdekatan dengan pantai kuta, selain itu juga pekerja/buruh diberikan waktu penyesuaian lingkungan kerja dengan alat-alat yang dipergunakan di hotel yang belum terbisa digunakan. (wawancara pada tanggal 19 September 2018).

Berdasarkan hasil wawancara, pihak Hotel Bintang Bali Resort sudah memberikan jaminan sosial kepada para pekerja/buruh harian lepas. Para pekerja/buruh harian lepas mendapatkan kelas BPJS II, dimana biaya perbulannya adalah sebesar Rp 51.000. Biaya BPJS tersebut dibayarkan oleh perusahaan sebesar 40\%, dan sisanya sebesar $60 \%$ dipotong langsung dari gaji pekerja/buruh harian lepas tersebut.

Hak Atas Perlindungan Keselamatan dan Kesehatan Kerja (K3) berdasarkan Pasal 87 Undang-Undang Nomor 13 Tahun 2003 tentang Ketenagakerjaan menyatakan bahwa setiap perusahaan wajib menerapkan sistem manajemen keselamatan dan kesehatan kerja yang terintegrasi dengan sistem manajemen perusahaan dan ketentuan mengenai penerapan sistem manajemen keselamatan dan kesehatan kerja sebagaimana dimaksud dalam ayat (1) diatur dengan Peraturan Pemerintah. ${ }^{9}$

Salah satu contoh perihal pemberiaan keselamatan dan kesehatan kerja (K3) di Hotel Bintang Bali Resort kepada

\footnotetext{
${ }_{9}$ Abdul Khakim, op.cit., h. 318
} 
pekerja/buruh harian lepas dan seluruh pekerja lainnya adalah dimana di setiap bagian, terdapat pemadam api yang tersedia dan dalam kondisi siap pakai. Selain itu terdapat klinik di dalam hotel yang menyediakan P3K jika terdapat pekerja yang mengalami kecelakaan kerja.

\subsubsection{Hambatan Dalam Pelaksanaan Hak-Hak Pekerja Harian Lepas Pada Hotel Bintang Bali Resort}

Faktor-faktor penghambat tidak terlaksananya pemberian hakhak pekerja harian lepas pada Hotel Bintang Bali Resort dalam hal ini adalah pemberian hak cuti yang dibayarkan, dikarenakan industri perhotelan merupakan industri yang harus terus beroperasi selama 24 jam 7 hari seminggu, sehingga para pekerja harian lepas tidak dapat mendapatkan hak cuti.

Jika kita lihat, hal yang dinyatakan oleh Pak Muhadir sebagai Human Resource Manager tidak ada korelasinya antara pemberian cuti dengan waktu pengoprasian Hotel selama 24 jam 7 hari seminggu. Mengenai hak cuti berkaitan langsusng dengan waktu kerja pekerja/buruh harian lepas pada Hotel Bintang Resort tersebut. Sedangkan, 24 jam kerja dalam sehari itu adalah kareakteristik oprasional jasa yang di jalankan oleh Hotel. Waktu kerja yang terlaksana pada Hotel Bintang Bali Resort adalah 8 (delapan) jam 1 (satu) hari dan 48 (empat puluh delapan) jam 1 (satu) minggu untuk 6 (enam) hari kerja dalam 1 (satu) minggu. Hal ini tidak sesuai dengan ketentuan Pasal 77 ayat (2) huruf b Undang-Undang Nomor 13 Tahun 2003 tentang Ketenagakerjaan "8 (delapan) jam 1 (satu) 
hari dan 40 (empat puluh) jam 1 (satu) minggu untuk 5 (lima) hari kerja dalam 1 (satu) minggu". ${ }^{10}$

Berdasarkan Pasal 79 ayat (1) menyatakan "pengusaha wajib memberikan waktu istirahat dan cuti kepada pekerja/buruh". Selanjutnya Pasal 93 ayat (2) huruf g menyatakan "pengusaha wajib membayar upah pekerja/buruh apabila pekerja/buruh melaksanakan hak istirahat". Jadi setiap pekerja/buruh harian lepas yang sedang menjalankan hak istirahat/cuti harus tetap dibayarkan oleh pengusaha, jika tidak dilaksanakan oleh pengusaha dapat dikenakan sanksi sesuai Pasal 186 ayat (1) menyatakan "barang siapa melanggar ketentuan sebagaimana dimaksud dalam Pasal 35 ayat (2) dan ayat (3), Pasal 93 ayat (2), Pasal 137, dan Pasal 138 ayat (1), dikenakan sanksi pidana penjara paling singkat 1 (satu) bulan dan paling lama 4 (empat) tahun dan/atau denda paling sedikit Rp. 10.000.000,00 (sepulu juta rupiah) dan paling banyak Rp. 400.000.000,00 (empat ratus juta rupiah)".

Dapat dikatakan pihak Hotel Bintang Bali Resort belum memahami pengaturan mengenai hubungan kerja waktu tertentu, dan hak cuti yang dibayarkan. (hal ini dapat dikategorikan sebagai faktor kesadaran hukum dari pihak pemberi kerja).

\section{PENUTUP}

\subsection{Simpulan}

Pelaksanaan hak-hak pekerja/buruh harian lepas dalam hal ini termasuk kedalam sistem perjanjian kerja waktu tertentu (PKWT) pada Hotel Bintang Bali Resort belum berjalan sesuai aturan yang

10 Asri Wijayanti, 2010, Hukum Ketenagakerjaan Pasca Reformasi, Sinar Grafika, Jakarta, h. 108 
berlaku, karena masih adanya kesenjangan dalam pelaksanaanya, yaitu di bidang hak cuti yang dibayarkan, serta hak untuk menjadi pekerja tetap.

Hambatan yang dihadapi dalam terlaksananya pemberian hakhak pekerja harian lepas pada Hotel Bintang Bali Resort adalah aturan perusahaan mengenai jumlah karyawan tetap sehingga pekerja harian lepas tidak dapat langsung diangkat menjadi pekerja tetap setelah bekerja lebih dari tiga tahun. Faktor kesadaran hukum yang belum memahami peraturan dari pihak Hotel Bintang Bali Resort mengenai hubungan kerja perjanjian kerja waktu tertentu, dan hak cuti yang dibayarkan.

\subsection{Saran}

Agar pihak manajemen Hotel Bintang Bali Resort memberikan hak-hak pekerja harian lepas sesuai dengan ketentuan UndangUndang Nomor 13 Tahun 2003 tentang Ketenagakerjaan yang berlaku seperti pemberian hak cuti dibayarkan, dan memperbaiki sistem perpanjangan atau pembaharuan perjanjian kerja waktu tertentu (PKWT).

Hendaknya pihak manajemen Hotel Bintang Bali Resort segera memperbaiki sistem hubungan kerja dalam pelaksanaan perjanjian kerja waktu tertentu (PKWT) sesuai dengan ketentuan yang ada di dalam Undang-Undang Nomor 13 tahun 2003 Tentang Ketenagakerjaan, terutama masalah perpanjangan atau pembaharuan kontrak kerja pada pekerja harian lepas yang terikat dalam perjanjian kerja waktu tertentu (PKWT) agar semua pekerja harian lepas segera mendapatkan haknya menjadi pegawai tetap (PKWTT). 


\section{DAFTAR PUSTAKA BUKU-BUKU}

Fakultas Hukum Universitas Udayana, 2013, Pedoman Pendidikan Fakultas Hukum Universitas Udayana, Denpasar

Khakim, Abdul, 2009, Dasar-Dasar Hukum Ketenagakerjaan Indonesia, PT. Citra Aditya Bakti, Bandung.

Udiana, Made, 2011, Rekonstruksi Pengaturan Penyelesaian Sengketa Penanaman Modal Asing, Udayana University Press, Denpasar , Made, 2015, Kedudukan Dan Kewenangan Pengadilan Hubungan Industrial, Udayana University Press, Denpasar

Wijayanti, Asri, 2010, Hukum Ketenagakerjaan Pasca Reformasi, Sinar Grafika, Jakarta

Wahyudi, Eko, 2016, Hukum Ketenagkerjaan, Penerbit Sinar Grafika, Jakarta

\section{Undang-Undang}

Indonesia, Undang-Undang Nomor 13 Tahun 2003 Tentang Ketenagakerjaan, Lembaran Negara Republik Indonesia Tahun 2003 Nomor 39 dan Tambahan Lembaran Negara Republik Indonesia Nomor 4279.

Peraturan Menteri Tenaga Kerja Dan Transmigrasi Republik Indonesia Nomor: PER-100/MEN/VI/2004 Tentang Pelaksanaan Perjanjian Kerja Waktu Tertentu.

Peraturan Gubernur Bali Nomor 65 Tahun 2017 Tentang Upah Minimum Kabupaten/Kota 


\section{Jurnal}

Cristoforus Valentino Alexander Putra, 2017, "Urgensi Klausula Definisi Dalam Perjanjian Kerja", Kertha Patrika, vol. 39, no. 1, April 2017, h. 70, https://ojs.unud.ac.id/index.php/kerthapatrika/article/dwonl oad/32709-949-63923-1-10-20170803.pdf. Diakses tanggal 23 Januari 2019 pukul 11.00 WITA

I Wayan Agus Vijayantera, 2016, "Pengaturan Tunjangan Hari Raya Keagamaan Sebagai Hak Pekerja Setelah Diterbitkan Peraturan Menteri Tenaga Kerja Nomor 6 Tahun 2016", Kertha Patrika, vol. 38, no. 1, Januari-April 2016, h. 44, https://ojs.unud.ac.id/index.php/kerthapatrika/article/down1 oads/30091-1-58616-1-10 20170420.pdf. Diaskses tanggal 23 Januari 2019 pukul 11.00 WITA 